\title{
膀胱粘膜上皮の非腫瘍性組織变化に関する検討
}

\author{
第 2 報：バルーンカテーテル留置による影響
}

\begin{tabular}{|c|c|c|c|}
\hline 国立善通寺病陌 & 山 & 本 & 晶 \\
\hline 米田文男) & 米 & 田 & 文 \\
\hline $\begin{array}{l}\text { 徳島大学医学部第 } 2 \text { 病理 } \\
\text { (主任: 大塚 久教授) }\end{array}$ & 赤 & 木 & \\
\hline
\end{tabular}

\section{HISTOLOGICAL STUDIES ON NON-NEOPLASTIC LESIONS OF THE URINARY BLADDER EPITHELIUM}

Second Report: The Influence of Indwelling Catheterization

Akihiro Yamamoto and Fumio Yoneda

Department of Urology, Zentsuji National Hospital, Kagawa, Japan

(Chief: F. Yonada)

Go Akagi

Second Department of Pathology, School of Medicine, Tokushima University, Tokushima, Japan

(Director: Prof. H. Otsuka)

Histopathological changes of the bladder epithelium in 33 male and 2 female patients treated with indwelling catheterization was studied by mucosal biopsies. The duration of indwelling catheterization ranged from 1 month to 9 years, with an average of 2 years and 5 months. Dysplasia and hyperplasia were detected in $5(14.3 \%)$ and $8(22.9 \%)$ of 35 cases, respectively. Squamous metaplasia, columnar metaplasia, Brunn's nests and cystitis glandularis were seen in $5(14.3 \%), 4(11.4 \%), 13(37.1 \%)$ and 3 $\mathbf{( 8 . 6 \% )}$ of cases, respectively. Cuboidal metaplasia was found in only one case. Lymphocytic infiltration in the lamina propria was observed in all cases. Dysplasia and squamous metaplasia were not detected in patients with indwelling catheterization for less than 1 year. Compared with patients free from catheters, dysplasia, hyperplasia and columnar metaplasia were more frequent in patients with catheterization. In male patients with catheterization, the incidence of squamous metaplasia was also high. Since some of these lesions are considered to be premalignant conditions, patients with long-term indwelling catheterization should be examined periodically by cytology and cystoscopy.

要旨: バルーンカテーテル留置中の35例に対し膀腃生検を施行し, 粘膜上皮の病理組織学的变化を検討 した. 35例中男性33例, 女性 2 例で, 留置期間は 1 カ月より 9 年まで, 平均 2 年 5 カ月であった. 全例腫瘍変化はみられず, Brunn's nests が13例（37.1\%）飞，以下 hyperplasia 8 例 $(22.9 \%)$, dysplasia, squamous metaplasia 各 5 例 (14.3\%), columnar metaplasia 4 例 (11.4\%), cystitis glandularis 3 例 (8.6\%), cuboidal metaplasia 1 例 (2.9\%) がみられた. また全例粘膜固有層のリン 八球浸潤がみられたが，留置期間が 1 年以下の症例に著明なものが多く，留置して 1 年までは著明な炎 症が起きるが，それを過ぎると軽減するものと考学られた。また dysplasia と squamous metaplasia は 留置期間が 1 年以下の症例ではみられず，この 2 つの変化は短期間では発生しないことが推測された。

第 1 報で報告したカテーテル非留置症例の結果と比較すると, 留置群に招いて dysplasia, hyperplasia, columnar metaplasia が有意に高頻度でみられた。 また男性の squamous metaplasia も留置群 で高頻度にみられた。 これらの変化は pre malignant と考光られているため, 長時間のバルーンカテー テル留置症例に対しては定期的な尿細胞診, 膀胼鏡等の検査が必要であり, そして, まず可能な限り長 期間の留置を避ける努力をすることが肝要と思われる。 


\section{はじめに}

泌尿器科疾患に扔いて時に長期間のバルーンカテー テル留置を余儀なくされる場合がある，その膀胱粘膜 に及ぼす影響についての系統的な報告は少ないが，膀 胱癌の発生頻度が高くなるといら報告が散見され $3^{122)}$. 今回われわれはバルーンカテーテル留置患者 35 例の膀胱粘膜の病理組織学的変化を生検により検討し たので，若干の文献的考察を加えて報告する.

\section{対象と方法}

国立善通寺病院に招いて昭和56年に膀胼内バルーン カテーテル留置中の35例を対象とした。男性33例，女 性 2 例で, 年齢は57歳より93歳, 平均年齢75.3歳であっ た。 バルーンカテーテル留置が必要となった疾患は, 前立腺肥大症 26 例, 神経因性膀胱 7 例, 前立腺癌 2 例 であった。留置方法は経尿道的留置33例，膀胱瘦 2 例 であった。留置期間は最短 1 カ月より最長 9 年間まで で，35例の平均期間は 2 年 5 カ月であった。膀胱生検 法は膀脱鏡検查を施行し膀胱三角部をたは側壁の粘膜 を生検鉗子にて $1 \sim 2$ 力所採取し, H.E.染色を行っ た。病理組織学的変化として第 1 報泉と同様に Koss, L.G.: Tumors of the Urinary bladder. Atlas of Tumor Pathology. Second series, AFIP.4) に従い Brunn's nests, cystitis glandularis, squamous metaplasia, columnar metaplasia, cuboidal metaplasia, hyperplasia, dysplasia を観察し,さらにリンパ球浸潤 の程度を $\mathrm{Ito}^{5}$ らの分類に従いgrade $1 \sim 3$ に分けた。 また統計学的有意差は $\chi^{2}$ 検定によった。

\section{結 果}

膀脱鏡的にも病理組織学的にも腫瘍性病変は認めら れなかった．35例中最も頻度が高った変化は Brunn's nests で13例（37.1\%）にみられた。以下 hyperplasia
8 例 $(22.9 \%)$, dysplasia, squamous metaplasia 各 5 例 $(14.3 \%)$, columnar metaplasia 4 例 (11.4\%) cystitis glandularis3 例 $(8.6 \%)$, cuboidal metaplasia 1 例（2.9\%）がみられた。結局35例中23例（65.7\%） に以上述べた変化のいずれかがみられた。リンパ球浸 潤は全例にみられ，grade 1, 16例（45.7\%），grade 2, 15例 (42.9\%), grade 3，4 例 (11.4\%) であった.

次にこれらの変化とバルーンカテーテル留置期間と の関係を Table 1 に示す。Brunn's nests は 1 カ月よ り 4 年 8 カ月まで, hyperplasia は 1 カ月より 9 年ま でと広い範囲にみられ，明らかな留置期間との関係は 認められなかった。それに対し， dysplasia, squamous metaplasia は各 5 例ずつみられたが, いずれも 1 年以 下の症例は認められず, これらの変化が短期問では発 生しないことが推測された。その他 columnar metaplasia, は 7 力月 2 例, 1 年 3 力月, 4 年 8 力月各 1 例 に, cystitis glandularis は 7 カ月に 1 例， 4 年 8 カ月 に 2 例, cuboidal metaplasia は 1 年 3 カ月に 1 例みら れた。な拉前立腺癌のため抗男性ホルモン療法を施行 した 2 例ともに squamous metaplasia がみられた。

リンパ球浸潤と留置期間との関係をみると 1 年以下 の13例では grade 1 は 4 例と少なく, grade 2, grade 3 が多かったが，1年を越える22例の中では grade 1 12例, grade 2 10例であり grade 3 はみられなかった。 以上の結果よりバルーンカテーテルを留置して 1 年ま では著明な炎症が起きるが，それを過ぎると炎症が軽 減するものと考光られる。

次にわれわれが第 1 報3で報告したバルーンカテー テル非留置132例の膀胱生検の結果とこれらの病理組 織学的変化につき比較検討を行った（Table 2)。 dysplasia, hyperplasia は非留置群では132例中それぞ

Table 1 Summary of 35 patients treated with indwelling catheterization

\begin{tabular}{|c|c|c|c|}
\hline \multirow[b]{2}{*}{$\begin{array}{l}\text { Histologic finding } \\
\text { in bladder }\end{array}$} & \multicolumn{3}{|c|}{ No. of Pts. / Duration } \\
\hline & $\begin{array}{c}<1 y_{0} \\
(M: 12, F: 1)\end{array}$ & $\begin{array}{c}1-3 y \\
(M: 14, F: 0)\end{array}$ & $\begin{array}{c}4 y \cdot< \\
(M: 7, F: 1)\end{array}$ \\
\hline Brunn's nests & $6(46.2 \%)$ & $5(35.7 \%)$ & $2(25.0 \%)$ \\
\hline Hyperplasia & $3(23.1 \%)$ & $3(21.4 \%)$ & $2(25.0 \%)$ \\
\hline Dysplasia & 0 & $2(14.3 \%)$ & $3(37.5 \%)$ \\
\hline Squamous metaplasia & 0 & $2(14.3 \%)$ & $3(37.5 \%)$ \\
\hline Columnar metaplasia & $2(15.4 \%)$ & $1(7.1 \%)$ & $1(12.5 \%)$ \\
\hline Cystitis glandularis & $1(7.7 \%)$ & 0 & $2(25.0 \%)$ \\
\hline Cuboidal metaplasia & 0 & $1(7.8 \%)$ & 0 \\
\hline $\begin{array}{l}\text { Grade of lymphocytic } \\
\text { infiltration } \\
\text { Grade } 1 \\
\text { Grade } 2 \\
\text { Grade } 3\end{array}$ & $\begin{array}{l}4 \\
5 \\
4\end{array}$ & $\begin{array}{l}8 \\
6 \\
0\end{array}$ & $\begin{array}{l}4 \\
4 \\
0\end{array}$ \\
\hline
\end{tabular}


Table 2 Comparison of various epithelial lesions between patients with and without indwelling catheterization

\begin{tabular}{|c|c|c|}
\hline & $\begin{array}{l}\text { With } \\
\text { catheterization (35cases) }\end{array}$ & $\begin{array}{l}\text { Without } \\
\text { catheterization (132cases) }\end{array}$ \\
\hline & No. cases $(\%)$ & No. cases $\left(\frac{\circ}{8}\right)$ \\
\hline Brunn's nests & $13(37.1)$ & $52(39.4)$ \\
\hline Hyperplasia & $8 \quad(22.9)$ & $13(9.8)$ \\
\hline Dysplasia & $5 \quad(14.3)$ & $5(3.8)$ \\
\hline Squamous metaplasia & $5 \quad(14.3)$ & $16(12.1)$ \\
\hline Columnar metaplasia & $4(11.4)$ & $2(1.5)$ \\
\hline Cystitis glandularis & $3(8.6)$ & $21(15.9)$ \\
\hline \multirow[t]{3}{*}{ Cuboidal metaplasia } & $1(2.9)$ & $1(0.8)$ \\
\hline & $\begin{array}{l}\text { With } \\
\text { catheterization (33cases) }\end{array}$ & $\begin{array}{l}\text { Without } \\
\text { catheterization ( } 55 \text { cases) }\end{array}$ \\
\hline & No. cases $(\%)$ & No. cases $\left(\frac{\circ}{0}\right)$ \\
\hline $\begin{array}{l}\text { Squamous metaplasia } \\
\text { in men }\end{array}$ & $5 \quad(15.2)$ & $2(3.6)$ \\
\hline
\end{tabular}

Fig. 1 Hyperplasia. An increased of cell layers without cellular atypia $\times 200$

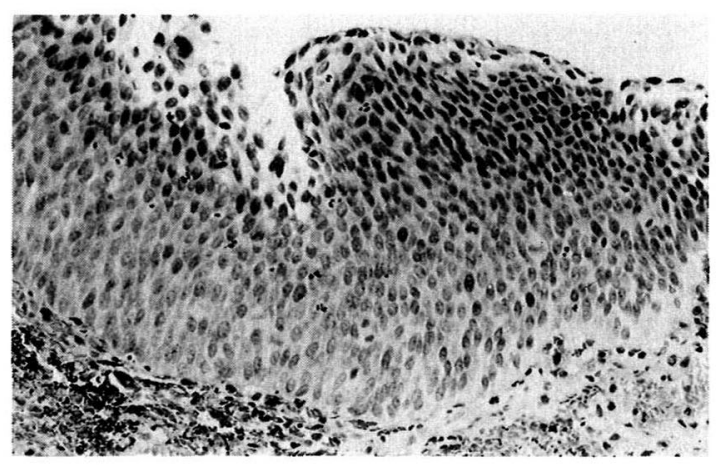

れ 5 例 (3.8\%)，13例 (9.8\%) であるのに対し, 留置 群では35例中 5 例 (14.3\%) と 8 例 (22.9\%) で，有 意に留置群で高い頻度に認められた（それぞれ $\mathrm{p}<$ $0.01, \mathrm{p}<0.02)$. さらに columnar metaplasia ๖, 非 留置群では 2 例（1.5\%）に対し留置群 4 例（11.4\%） と後者で有意に高頻度に認められた $(\mathrm{p}<0.01)$.

hyperplasia, columnar metaplasia を Fig. 1, 2 に 示す. squamous metaplasia は非留置群においても女 性では比較的よくみられるため, 男女合わせると両群 間に明らかな差は認められないが，男性のみを比較す ると非留置群では55例中 2 例(3.6\%)であるのに対し, 留置群では33例中 5 例 (15.2\%) と留置群で有意に高 かった（p<0.05）。そのらち2 例は抗男性ホルモン療 法を施行していた。またいわゆる leukoplakia ${ }^{6}$ はみら れなかった. Brunn's nests は両群間に明らかな頻度の 差はなく, cystitis glandularis は逆に非留置群でやや
Fig. 2 Columnar metaplasia. Transitional epithelium is replaced by columnar cells $\times 400$

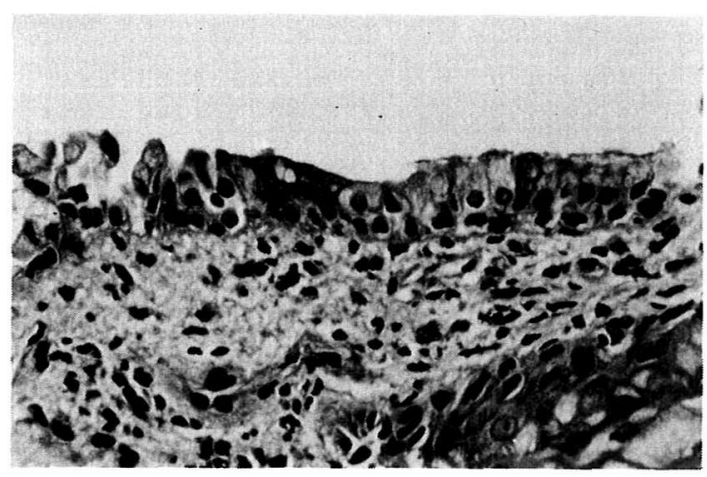

高かった。

cuboidal metaplasia は両群とも 1 例ずつでまれな 変化であった。

\section{考察}

脊䯣損傷患者で長期間カテーテルを留置していた症 例に膀胱癌, 特に squamous cell carcinoma が多いと いら報告がみられる12)。さらに Kaufman'1) は squamous metaplasia について，カテーテル非留置患

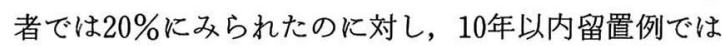
$42 \%$ に，10年以上留置ではその $80 \%$ にられたと報告 している.また, Broecker らは脊損患者1,052例のら ら膀胱癌を10例に認め, 一般の頻度よりかなり高かっ た事より同様の検討を行っている、それによると 10 年 以上カテーテルを留置している50例のうち carcinomaは全くみられなかったが, squamous meta. plasia が11例 (22\%) に認められ, cystitis glandularis 
が 4 例 ( $8 \%$ ), leukoplakia が 1 例, さらに hyperplasia が15例（30\%）に認められたと報告している. 一般に squamous metaplasia は女性では比較的よく みられるも，男性ではをれであるといわれている

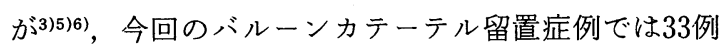
中 5 例 $(15.2 \%)$ にみられた。 5 例中 2 例は前立腺癌 のため抗男性ホルモン療法を施行している。女性ホル モンによりこの変化が起り易くなるという報告もあ $\eta^{4)}$ ，バルーンカテーテルによる機械的刺激に加えて, 抗男性ホルモン療法の影響も否定できない。また留置 期間が 1 年以下の症例にはこの変化はみられず squamous metaplasia の発生にはかなりの期間が必 要と思われる。

dysplasia, hyperplasia は非留置群に比較し明らか に留置群で高頻度にみられた。dysplasiaは premaligenant と考兄られ膀胼癌患者では非腫瘍部粘 膜にもしばしばみられる47). われわれの経験した dysplasia の 5 例をみると比較的長期間留置例が多 く, 1 年以下の症例にはみられなかった. 5 例とも mild-moderate dysplasiaであったため特に処置は 行っていないが，尿細胞診等による十分な follow up が必要と思われる. hyperplasiaは一般には可逆性変 化で，多くは原因が除去されれば，正常粘膜に戻り， 一部のものが腫瘍性変化に移行すると考兄られてい $ろ^{8)}$. バルーンカテーテル留置症例に拀いてはた觉ず 刺激が加わっており, 後者の経過をたどる可能性も考 えられる。

columnar metaplasia も留置群に打いて明らかに高 頻度にみられた。

以上の結果より dysplasia, hyperplasia, columnar metaplasia はバルーンカテーテル留置による機械的 刺激と炎症により発生しやすくなると考㝋られ, さら に男性の squamous metaplasia るとの可能性が考光 られる。一方 Brunn's nests, cystitis glandularis の出 現頻度は非留置群と比較すればむしろ低值をしめして いた。しかし辻ら ${ }^{9 /}$ は家鬼膀胼内結石插入実験を行い, 結石插入後, 9 日後にはすでに炎症が慢性化に傾くと 共に上皮の陰窩増殖がはじまっているとのべており異 物による早期の陰窩形成を示唆している.

cuboidal metaplasia は非留置群と同様, 留置群も 1 例みられたのみでまれな变化であった。

今回，われわれの得た結果は膀胱の 1,2 力所のみ の生検によるものであり, 多くの結論を出す事は困難 である。しかし premalignant leaions と考学られてい
る dysplasia, hyperplasia および男性の squamous metaplasia の頻度が非留置群に比較して高かったこ とより, バルーンカテーテル長期留置症例では, その 点を考慮した follow up が必要であると考兄られる. 従ってこのよらな症例では定期的な尿細胞診を行い， 適宜，膀胼鏡，生検等を施行することが必要であり， 可能なかぎり長期間バルーンカテーテルの留置をさけ る努力をすることが肝要と思われる.

\section{まとめ}

バルーンカテーテル留置中の35例に膀胼生検を施行 し，その病理組織学的変化を検討した。

1）癌の発生は認められず, 最も多い変化はBrunn's nests で13例（37.1\%）にみられた。 以下 hyperplasia 8 例 (22.9\%), dysplasia, squamous metaplasia 各 5 例 $(14.3 \%)$, columnar metaplasis 4 例 $(11.4 \%)$, cystitis glandularis 3 例 (8.6\%) がみられ, cuboidal metaplasia は1例 (2.9\%) にみられたのみであった。 リンパ球浸潤は全例にみとめられた。

2) dysplasia, squamous metaplasia は留置期間が 1 年以下の症例にはみられなかった.

3）非留置群の変化と比較すると, dysplasia, hyperplasia, columnar metaplasia は留置群で明らかに高 頻度にみられ, 男性の squamous metaplasia もその可 能性が考えられた。

(本論文の要旨は第70回日本泌尿器科学会総会に拄いて 発表した。稿を終えるにあたり, 御校閲をたまわった德島大 学第二病理学教室大塚久教授に深謝します.)

\section{文献}

1) Kaufman, J.M., et al.: Bladder cancer and squamous metaplasia in spinal cord injury patients. J. Urol., 118, 967-971, 1977.

2) Broecker, B.H., et al.: Cancer of the bladder in spinal cord injury patients. J. Urol., 125, 196--197, 1981.

3）山本晶弘, 他：膀腅粘膜上皮の非腫場性組織变化 飞関する検討. 第 1 報：132生検例について。 日泌 尿会誌，000，000-000，0000。

4) Koss, L.G.: Tumors of the urinary bladder. Atlas of Tumor Pathology. Second series, Armed Forces Institute of Pathology, Washington, 1975.

5) Ito, N., et al.: Lesions of the urinary bladder epithelium in 125 autopsy cases. Acta Pathol. Jpn., 31, 545-557, 1981.

6) Wiener, D.P., et al.: The prevalence and significance of Brunn's nests, cystitis cystica and squamous metaplasia in normal bladders. J. 
Urol., 122, 317-321, 1979.

7) Heney, N.M., et al.: Biopsy of apparently normal urothelium in patients with bladder carcinoma. J. Urol., 120, 559-560, 1978.

8）村崎元五：膀胼癌発生過程の経時的変化とくにそ の前癌变化に関する実験的研究. 名市大医誌, 29,
112-127, 1978.

9）过一郎, 黒田恭一, 高瀬吉雄: 尿路上皮化生の研 究. (第 2 報). 家鬼膀胱内結石挿入実験. 日泌尿会 誌, 42, 306-312, 1951.

（1983年 8 月 10 日受付） 